\title{
DWORKIN ON THE VALUE OF INTEGRITY
}

\author{
JonAthan CROWE*
}

[This article explores and critiques Ronald Dworkin's arguments on the value of integrity in law. Dworkin presents integrity in both legislation and adjudication as holding inherent political value. The author defends an alternative theory of the value of integrity, according to which integrity holds instrumental value as part of a legal framework that seeks to realise a particular set of basic values taken to underpin the legal system as a whole. It is argued that this instrumental-value theory explains the value of integrity more satisfactorily than Dworkin's inherent-value account. The article concludes with a discussion of Dworkin's 'one right answer thesis'. Although the proposed theory of integrity does not support a strong version of Dworkin's thesis, it does suggest that there will be a single correct answer to legal questions more often than for normative deliberation generally.]

The writings of Ronald Dworkin have exercised enormous influence on contemporary legal theory. ${ }^{1}$ Dworkin's account of law centres on his theory of adjudication. In an early article, he goes so far as to characterise the question, 'what is law?', as merely a truncated statement of the more central issue, 'what, in general, is a good reason for decision by a court of law?' One of the pivotal ideas in Dworkin's theory of adjudication is the notion of integrity, which he treats as a fundamental and distinctive political value. In

\footnotetext{
${ }^{*}$ Lecturer and Fellow, Centre for Public, International and Comparative Law, T C Beirne School of Law, University of Queensland. I would like to thank Tom Campbell, John Gardner and Suri Ratnapala for their helpful comments on earlier versions of this paper. All remaining errors are, of course, entirely my own.

${ }^{1}$ The extent of Dworkin's influence is generally acknowledged, but for an amusing and perceptive view to the contrary see Brian Leiter, 'The End of Empire: Dworkin and Jurisprudence in the 21st Century' (2005) 36 Rutgers Law Journal 165.

2 Ronald Dworkin, 'Does Law Have a Function? A Comment on the Two-Level Theory of Decision' (1965) 74 Yale Law Journal 640, 640.
} 
this article, I explore and critique Dworkin's comments on the value of this concept. $^{3}$

Dworkin treats integrity in both legislation and adjudication as holding inherent political value; that is, he argues integrity is valuable in and of itself. He supports this position by appealing to our deeply held intuitions about the undesirability of certain legal practices that reject integrity. The main aim of this article is to suggest an alternative theory of the value of integrity, according to which integrity holds instrumental value as part of a legal framework that seeks to realise a particular set of basic values taken to underpin the legal community. I suggest that this instrumental-value account explains our intuitions about the value of integrity more satisfactorily than Dworkin's inherent-value theory.

The article has three parts. Part I introduces Dworkin's notion of integrity and outlines his explanation of its political value. In Part II, I introduce my alternative explanation for the value of integrity and explain how it improves upon Dworkin's account. Finally, Part III discusses the relationship between Dworkin's notorious 'one right answer thesis' and my proposed theory of integrity. I argue that, although the notion of integrity does not support a strong version of the one right answer thesis, it does suggest that there will be a single correct answer to legal questions more often than for normative deliberation generally.

\section{DWORKIN'S THEORY OF INTEGRITY}

Dworkin's theory of law has developed significantly over time. The focus here is on the most comprehensive version to date, outlined in Law's Empire. In that work, Dworkin famously analyses judicial decision-making as comprising three stages. ${ }^{4}$ The first is a preinterpretive stage in which the rules and standards that hold relevance for the case at hand are tentatively identified. The second is an interpretive stage where the judge formulates a

\footnotetext{
${ }^{3}$ There have been other influential accounts of integrity, which I do not consider in detail here. See particularly Gerald J Postema, 'Integrity: Justice in Workclothes' (1997) 82 Iowa Law Review 821. Debates concerning Dworkinian integrity also connect to some extent with discussions about the value of coherence in law. See, for eg, Robert Alexy and Aleksander Peczenik, 'The Concept of Coherence and Its Significance for Discursive Rationality' (1990) 3 Ratio Juris 130; Joseph Raz, 'The Relevance of Coherence' (1992) 72 Boston University Law Review 273.

${ }^{4}$ Ronald Dworkin, Law's Empire (1986) 65-8.
} 
general theory of the motivations and rationales underlying the elements of practice identified in the previous stage. Finally, at the postinterpretive stage, the judge forms a view about what decision the prevailing social practice requires in the present case, taking into account the general framework of justification posited at the preceding step.

The interpretive stage of the above process introduces an explicitly purposive element into legal deliberation. The use of a general theory outlining the principles and values underpinning the salient legal rules is arguably the core element of Dworkin's theory of legal adjudication. This purposive dimension in Dworkin's theory is closely related to his notion of law as integrity.

Dworkin treats integrity as a distinctive political value. He initially divides this concept into two parallel notions, corresponding to two different types of legal decision making: integrity in legislation and integrity in adjudication. Integrity in legislation requires the legislature to make the law coherent, bearing in mind a set of overarching values. ${ }^{5}$ Integrity in adjudication requires judges to treat the law 'as expressing and respecting a set of coherent principles'. ${ }^{6}$ On this view, legal deliberation contains both backward- and forward-looking elements; legal practice is seen as 'an unfolding political narrative. ${ }^{7}$

Dworkin's main example in favour of the value of integrity in legislation concerns 'checkerboard' laws that apply an arbitrary settlement to political disagreements. ${ }^{8}$ He frames the problem as follows:

Do the people of Alabama disagree about the morality of racial discrimination? Why should their legislation not forbid racial discrimination on buses but permit it in restaurants? Do the British divide on the morality of abortion? Why should Parliament not make abortion criminal for pregnant women who were born in even years but not for those born in odd ones? ${ }^{9}$

Dworkin argues that there is something inherently dismaying about checkerboard solutions to political differences. The reason for rejecting such solutions, however, is not immediately clear; after all, we readily accept other

\footnotetext{
${ }^{5}$ Ibid 176.

${ }^{6}$ Ibid 217.

${ }^{7}$ Ibid 225.

${ }^{8}$ Ibid $178-86$.

${ }^{9}$ Ibid 178.
} 
types of political compromises. 'Why', Dworkin queries, 'should we turn our back on checkerboard solutions as we do? ${ }^{10}$ His answer is that integrity holds intrinsic political value. We object to checkerboard statutes simply because 'a state that adopts these internal compromises is acting in an unprincipled way'. ${ }^{11}$ In accepting such compromises, 'the state lacks integrity because it must endorse principles to justify part of what it has done that it must reject to justify the rest. ${ }^{, 2}$

Dworkin argues that integrity in legislation is 'so much part of our political practice that no competent interpretation of that practice can ignore it. ${ }^{13}$ In this way, his claim about the political value of legislative integrity draws on an explanatory theory of our existing legislative practices: we can only satisfactorily explain these practices and the social attitudes that surround them if we credit integrity with inherent value. Dworkin proceeds to integrate this explanatory account of integrity into a broader interpretive theory of the political community: the notion of integrity is consistent with a 'community of principle' - a 'genuine associative community' capable of sustaining a plausible claim to moral legitimacy - rather than a 'rulebook community', which appears to be driven solely by power. ${ }^{14}$

Dworkin's argument for the value of integrity in adjudication takes a similar form. In the first place, it is an argument about the best explanation for judicial practice. For Dworkin, judicial interpretation of legal materials is structured by the notion of intention. ${ }^{15}$ The use of intention in legal interpretation, in turn, involves appealing to a set of general goals or principles in order to lend a coherent background context to particular legal rules. ${ }^{16}$ This interpretive theory of adjudication is then integrated into an overarching account of legal institutions as reflecting a particular notion of the legal community. It is at this more abstract level that the discrete principles of integrity in legislation and integrity in adjudication yield an overarching notion of law as integrity.

\footnotetext{
${ }^{10}$ Ibid 179 .

${ }^{11}$ Ibid 183 .

${ }^{12}$ Ibid 184 .

${ }^{13}$ Ibid 176

${ }^{14}$ Ibid 214.

${ }^{15}$ Ibid 228

${ }^{16}$ Ibid 51-3.
} 
Dworkin seeks to illuminate the methodology associated with integrity in adjudication through his now notorious example of 'the chain novel'. ${ }^{17} \mathrm{We}$ are asked to imagine an enterprise in which several authors cooperate to write a novel. Each author interprets the chapters she or he has been given in order to create a new chapter, which is then added to the materials received by the next author. The task of each author is to contribute to making the novel 'the best it can be', ${ }^{18}$ which will evidently involve striving for consistency in the narrative.

In order to achieve this goal, each author will need to 'take up some view about the novel in progress, some working theory' about its plot, theme, characters and so on. ${ }^{19}$ Arriving at such a theory will involve working out what possible interpretations 'fit' the extant chapters of the book and judging 'which of these eligible readings makes the work in progress best, all things considered. ${ }^{20}$ The latter judgement may involve an aesthetic dimension, but will generally be guided by the 'formal and structural considerations' noted at the first stage of the process. ${ }^{21}$ (In legal interpretation, Dworkin later observes, the aesthetic element of the process is replaced by a dimension of 'political morality'.22)

Dworkin describes his theory of adjudication as 'relentlessly interpretive', insofar as 'it is both the product of and the inspiration for comprehensive interpretation of legal practice. ${ }^{23}$ Importantly, Dworkin depicts law as integrity as closely tied to the contemporary context. Law as integrity 'does not aim to recapture ... the ideals or practical purposes of the politicians who first created it', but rather 'aims to justify what they did in an overall story worth telling now' ${ }^{24}$

There is an echo here of Hans-Georg Gadamer's conception of interpretation as involving a 'fusion of horizons'. ${ }^{25}$ Gadamer views understanding as involving a type of agreement between author and interpreter, negotiated through the text. Since there is 'an inevitable difference between the

\footnotetext{
${ }^{17}$ Ibid 228-38.

${ }^{18}$ Ibid 229.

${ }^{19}$ Ibid 230 .

${ }^{20}$ Ibid 230-1

${ }^{21}$ Ibid 231 .

${ }^{22}$ Ibid 239.

${ }^{23}$ Ibid 226.

${ }^{24}$ Ibid 227 (emphasis added).

${ }^{25}$ Hans-Georg Gadamer, Truth and Method (Garrett Barden and John Cumming trans, 1979) 273.
} 
interpreter and the author that is created by the historical difference between them', there is a sense in which 'every age has to understand a transmitted text in its own way. ${ }^{26}$ Textual interpretation therefore represents a dynamic process, in which 'old and new continually grow together to make something of living value. ${ }^{27}$ Dworkin's discussion of the interpretive attitude cites with approval Gadamer's view of interpretation 'as recognising, while struggling against, the constraints of history'. ${ }^{28}$

It is important to note that, in arguing for integrity as a discrete and independent political value, Dworkin does not commit himself to holding that integrity has value regardless of the legal and political context. Rather, he appears to see it as possessing independent value within a particular type of political community: specifically, a community founded on an AngloAmerican common law system. The argument, as Dworkin states it, is that 'our political practices accept integrity as a distinct value'; $;{ }^{29}$ that is, integrity 'is so much part of our political practice' that, in interpreting that practice, it cannot reasonably be ignored. ${ }^{30}$ Nonetheless, within such a legal environment, Dworkin sees integrity as intrinsically valuable; we need posit no other conditions or values to see that it is worthwhile.

\section{INTEGRITY IN THE CONTEXT OF VALUE}

Dworkin's theory amounts to an inherent-value view of integrity. On this view, integrity is valuable in and of itself, at least within a certain type of legal environment. The alternative, assuming integrity has value at all, is an instrumental-value analysis, according to which integrity holds value as a way of pursuing some other, more fundamental value or values. ${ }^{31}$ Let us

\footnotetext{
${ }^{26}$ Ibid 263.

27 Ibid 273

${ }^{28}$ Above n 4, 62. See also 55-9. For a critical assessment of Dworkin's appeals to Gadamerian hermeneutics, see Costas Douzinas, Shaun McVeigh and Ronnie Warrington, 'Is Hermes Hercules' Twin? Hermeneutics and Legal Theory' in Alan Hunt (ed), Reading Dworkin Critically (1992) 123.

${ }^{29}$ Above n 4, 178 (emphasis added).

${ }^{30}$ Ibid 176 (emphasis added).

${ }^{31}$ I use the terms 'inherent-value' and 'instrumental-value' here, rather than the more familiar 'deontological' and 'consequentialist', to make it clear I am not advancing any general claims about the nature of moral deliberation. My theory of integrity is certainly not consequentialist in the sense of promoting the maximisation of some overall notion of value. For further discussion, see Jonathan Crowe, 'Existentialism and Natural Law' (2005) 26 Adelaide Law Review 55.
} 
therefore explore what form an instrumental-value approach to integrity might adopt.

Suppose I am engaged by a political party to draft a policy statement. I am instructed that the policy document must be consistent with the platform of the party, which comprises a series of abstract principles. It seems clear that, in order to do the job well, I should do my best to ensure that my statement coheres in all respects with the principles in the platform; that is, I must pay attention to integrity. Integrity, in this situation, holds instrumental value: I must respect it in order to fulfil my brief of drafting a document that can be supported by the party platform. (We might imagine a parallel scenario where the party leaders brief me to produce a document that is politically expedient, whether or not it coheres with the broader values the party espouses; in such a case, integrity lacks the instrumental value it holds in the previous situation, whether or not it still retains some inherent value that I might autonomously wish to consider in approaching the task.)

Does Dworkin's argument for the value of integrity in Law's Empire rule out a instrumental-value analysis like the one just outlined? Let us begin by reconsidering Dworkin's discussion of checkerboard legislation. He points out that we are inclined to reject statutes that enact unprincipled, arbitrary compromises on contested political issues; his conclusion is that integrity holds intrinsic political value. Dworkin's conclusion represents one possible explanation of our attitude to checkerboard solutions, but it is not the only one. We might posit that people generally view the legal system as furthering a particular set of moral principles (whether or not they feel confident about their ability to enunciate exactly what those principles are); integrity can then be viewed as instrumental to respecting the specific principles at which the legal system is thought to aim. The latter explanation resembles the case outlined in the previous paragraph. It is as if the legislature has been briefed to draft laws that cohere with a particular normative 'platform' (although, of course, no person or group has deliberately compiled the platform or explicitly issued the direction to value it).

How are we to evaluate the two different explanations of the value of integrity outlined above? The matter is complicated by the particular sense in which Dworkin sees integrity as holding intrinsic value; as we have seen, he appears to restrict his claim to a particular type of legal community. Nevertheless, Dworkin systematically separates integrity from adherence to a particular moral framework. For instance, he denies that our rejection of checkerboard solutions merely reflects 'our conviction that no one should 
actively engage in producing' a result she or he thinks unjust. ${ }^{32}$ His objection to such an explanation is that if each legislator votes for the checkerboard compromise in order to 'give the maximum possible effect' to the values she or he endorses, it is not clear how anyone has behaved irresponsibly. ${ }^{33}$ However, the instrumental-value approach to integrity sketched above does not propose that integrity is instrumental to the diverse moral priorities of individual legal actors, but rather that it is instrumental to respecting a particular set of basic principles that are taken to ground the entire system of law. The latter view is quite capable of motivating a generalised objection to checkerboard statutes.

Dworkin advances a further reason for thinking that the value of integrity is not grounded in a particular moral platform, by pointing out two different ways that integrity and morality may seem to conflict. He argues first that integrity may sometimes override moral considerations, as when decisions in previous cases clearly support an outcome in a current case that the judge in that case finds morally objectionable. ${ }^{34}$ In a later passage, Dworkin canvasses the opposite possibility: moral considerations may sometimes override integrity. He suggests that the requirement of integrity may not always be 'absolutely sovereign over what judges must do at the end of the day', since 'other and more powerful aspects of political morality might outweigh this requirement in particular and unusual circumstances' ${ }^{35}$ He elaborates that where integrity in adjudication leads to what a judge sees as a deeply immoral result, the judge will have to either enforce the unjust rule, 'lie and say that this was not the law after all' or resign from the bench. ${ }^{36}$

The apparent possibility of moral reasons for action overriding integrity - or vice versa - arises from what Dworkin perceives as the disjunction between the 'grounds' and the 'force' of law. The grounds of law concern the circumstances in which particular propositions about law should be taken as true, while the force of law relates to the power any true proposition about law holds to justify 'the use of collective power against individual citizens or groups' ${ }^{37}$ Dworkin holds that any 'full political theory of law' will contain accounts of the grounds and force of law that are mutually supporting.

\footnotetext{
${ }^{32}$ Above n 4, 181.

${ }^{33}$ Ibid 181-2.

${ }^{34}$ Ibid $176-8$.

${ }^{35}$ Ibid 218-9.

${ }^{36}$ Ibid 219.

${ }^{37}$ Ibid 109-10. Compare Stephen Guest, Ronald Dworkin (1992) 82.
} 
Nevertheless, the two types of analysis are separable and the factors they raise may sometimes conflict. ${ }^{38}$

In this way, Dworkin's analysis of integrity in adjudication attempts to distinguish conscientious judgements about how to act in particular circumstances from legal reasoning, which includes an institutional dimension of political morality. In a similar vein, Stanley Fish notes that Dworkin's position 'suggests that there are two types of reasons - personal ones and institutional ones'. ${ }^{39}$ It is as if the judge displaces her or his 'personal' moral convictions in order to engage with law as integrity, then only reopens the moral status of the resulting decision under extreme conditions. As Dworkin puts it, the principle of integrity 'does not necessarily have the last word' in motivating action by legal agents, 'but it does have the first word, and normally there is nothing to add to what it says. ${ }^{40}$

The plausibility of Dworkin's stance on the relationship between law as integrity and moral judgement depends on his depiction of the former as prior to the latter. For Dworkin, integrity has 'the first word' in legal deliberation; a separate moral dimension arises only when there is something to add. However, Dworkin's analysis neglects what natural law theorists, such as John Finnis, ${ }^{41}$ have described as the pre-moral basis for normative deliberation. The notion of pre-moral value suggests that the social context within which normative deliberation occurs is imbued with ethical significance at the pre-reflective level. ${ }^{42}$ Dworkin treats particular ethical judgements as though they arise reflectively and can readily be dispensed with in favour of 'institutional' integrity. In fact, moral reasoning, as well as its legal counterpart, occurs within an institutional context; in this respect, as Fish recognises, ${ }^{43}$ the idea of a purely 'personal', non-grounded moral judgement is, strictly speaking, nonsense. Dworkin seems to conflate individual moral priorities (what Finnis calls 'basic commitments ${ }^{\text {,4 }}$ ), which

\footnotetext{
${ }^{38}$ Above n 4, 110-1, 218.

${ }^{39}$ Stanley Fish, 'Still Wrong After All These Years' (1987) 6 Law and Philosophy $401,411$.

${ }^{40}$ Above $\mathrm{n}$ 4, 219 (emphasis added).

${ }^{41}$ John Finnis, Natural Law and Natural Rights (1980) 34. See also Germain Grisez, Joseph Boyle and John Finnis, 'Practical Principles, Moral Truth and Ultimate Ends' (1987) 32 American Journal of Jurisprudence 99, 126.

${ }^{42}$ For further discussion, see Jonathan Crowe, 'Levinasian Ethics and Legal Obligation' (2006) 19 Ratio Juris 421.

${ }^{43}$ Above n 39, 411.

${ }^{44}$ Above n 41, 90-1. Compare Grisez, Boyle and Finnis, above n 41, 140-1.
} 
might loosely be described as 'personal', with the shared judgements of value on which those priorities are grounded.

In order to do justice to the notion of pre-moral value, it is necessary to reverse the priority that law as integrity holds over ethical experience in Dworkin's account. Even if one is inclined to question the universality of the specific basic values that theorists such as Finnis have enumerated, it seems indisputable that these values are widely honoured and pursued within Anglo-American legal communities - the type of legal environment at which Dworkin's argument is directed. At this level, it is possible to regard premoral judgements of value as a species of social fact ${ }^{45}$ even if these basic judgements are not clearly universal or transcendental, they are shared, pervasive and, qua social phenomena, irrefutably real.

I have described these shared, pre-moral judgements elsewhere as social judgements of ethical significance. ${ }^{46}$ Such judgements are firmly embedded in the fabric of social discourse; to this extent, they are phenomenologically prior to legal reasoning. Once ethical judgements are recognised as prior to legal judgements, however, Dworkin's inherent-value view of integrity is revealed as empty, since it adds nothing to an explanatory theory of political discourse that the framework of pre-moral values does not already provide. Judgements of ethical significance provide a stable context within which people make reflective assessments about how to behave in morally significant spheres of action. It follows that, in making such assessments, people will wish to be consistent with the institutional requirements for ethical behaviour; furthermore, they will desire and expect the same principled attitude from others. This analysis applies to legal reasoning, which generally pertains to morally significant areas, as well as to other types of deliberation.

It is notable, in this context, that we tend to place high value on integrity in morally significant spheres of action, in a way that distinguishes it from other areas of experience, such as aesthetic enjoyment. It is true that if someone passing through an art gallery acclaims a particular painting, then expresses

${ }^{45}$ See Emile Durkheim, The Rules of Sociological Method (Sarah A Solovay and John H Mueller trans, 1964) ch 1. Durkheim defines a social fact as 'every way of acting, fixed or not, capable of exercising on the individual an external constraint' or, in other words, "every way of acting which is general throughout a given society, while at the same time existing in its own right independent of its individual manifestations.' See ibid 13.

${ }^{46}$ Above n 42, 425. See also above n 31, 71-2. 
disdain of the next item, even though it is in a similar style, one might well seek the reasons for her or his judgement. However, what if the person responds, 'I don't know. I just liked the last one better'? Such a response may be frustrating for the interlocutor, but it is not dismaying in the same way as a similar response to a moral question. People commonly feel that on moral issues there is a shared truth to be had and, furthermore, it is deficient not to seek it. The motivation for this belief is institutional, but it is by no means specifically legal. It is because law is necessarily situated within a socially embedded ethical framework that people object to inconsistent legal outcomes in morally significant spheres of action.

It is worthwhile to remind ourselves at this point of the nature of Dworkin's project. His account of the value of integrity rests upon an explanatory account of legal decision-making; this is then integrated into an overarching theory of the legal community. Dworkin observes - correctly, in my view that a wide-ranging hermeneutic theory of our legal practices supports the value of integrity. However, there is an important dimension of social action that remains outside his theory: the dimension of pre-moral value. This leads to an anomalous disjunction between social judgements of moral significance, which Dworkin appears to conflate with personal moral priorities, and the institutional dimension of political morality that figures in legal reasoning. A comprehensive explanatory theory of legal institutions would seek to integrate these aspects of normative experience.

Integrating the dimension of pre-moral value into Dworkin's interpretive theory of law improves the explanatory power of his account, by providing an additional explanatory context for the value of integrity. Dworkin's theory, in its current form, appeals to the notion of integrity to explain legal practices. However, integrity itself is afforded no real contextual explanation; it is simply posited as an intrinsic component of the ideal political community. The notion of pre-moral value, on the other hand, allows us to explain why integrity is valuable: it is instrumental to the ultimate social objective of respecting fundamental human values. This conception of the legal community as enabling the pursuit of basic forms of moral expression - what Finnis calls the "common good" ${ }^{47}$ - provides a rich explanatory framework for legal practices. Unlike Dworkin's account, it avoids positing an artificial separation between 'institutional' political morality and pre-moral judgements of ethical significance.

${ }^{47}$ Above n 41, 154-6. Compare John Finnis, Aquinas: Moral, Political and Legal Theory (1998) 113-4, 122-3. 
The view of integrity outlined above has the additional merit of defusing an important objection to Dworkin's theory. Larry Alexander and Ken Kress have argued that Dworkin's conception of integrity requires morally incorrect principles to be preferred to morally correct principles where the former are more consistent with the extant legal materials - a result they find puzzling for a number of reasons. ${ }^{48}$ However, I have argued that the practice of integrity ultimately rests on a set of basic values that are common to both moral and legal reasoning. These fundamental precepts figure in legal deliberation from the preinterpretive level. It follows from this account that only morally correct principles will fully satisfy Dworkin's dimension of 'fit': the best theory of the existing law will always be one that is consistent with the pre-moral basis of the legal community.

\section{IS THERE 'ONE RIgHt ANSWER'?}

Dworkin's account of legal interpretation as involving a background theory of 'fit' and 'political morality' has sometimes been interpreted as entailing that there is one correct answer to every case that comes before the judiciary. Stephen Guest describes this position, which he calls the 'one right answer thesis', as a doctrine that is 'not of Dworkin's own making, but which has been ascribed to him. ${ }^{49}$ Dworkin has, however, sometimes advanced strong views on the possibility of right answers in difficult cases of legal interpretation. In Taking Rights Seriously, he speaks of his suggested methodology as potentially supporting a 'seamless web' of principle that 'provides a coherent justification for all common law precedents'. ${ }^{50}$ Elsewhere, he argues that, 'in a modern, developed and complex [legal] system', the case where a 'best' answer is agreed not to exist would 'be so rare as to be exotic'. ${ }^{51}$ Likewise, in the Preface to Law's Empire, Dworkin proposes that 'in most hard cases there are right answers to be hunted by reason and imagination', although this does not mean that 'in these cases one answer could be proved right to the satisfaction of everyone'.

${ }^{48}$ Larry Alexander and Ken Kress, 'Against Legal Principles' (1997) 82 Iowa Law Review 739. See also Denise Réaume, 'Is Integrity a Virtue? Dworkin's Theory of Legal Obligation' (1989) 39 University of Toronto Law Journal 380.

${ }^{49}$ Above n 37, 137.

${ }^{50}$ Ronald Dworkin Taking Rights Seriously (1978) 115-6.

${ }^{51}$ Ronald Dworkin, A Matter of Principle (1986) 143.

${ }^{52}$ Above n 4, viii-ix. 
Let us consider Dworkin's stance on right answers in light of the theory of integrity suggested above. If the value of law as integrity is intertwined with the ethical basis of law, is there a 'best' answer to most, if not all, legal questions? The answer depends partly on whether, like Finnis, one views basic values as multiply realisable. ${ }^{53}$ According to the classical natural law outlook that Finnis endorses, there are often multiple responses to a moral quandary that show respect for pre-moral values, although certain reactions will be ruled out of court. ${ }^{54}$ If law as integrity derives its institutional context partly from pre-moral judgements of value, a similar analysis might be expected to apply to the legal context.

The above analysis suggests that, as Finnis argues in an article on Law's Empire, just as there are many different ways to go wrong in legal deliberation, so too are there multiple ways of getting it right. ${ }^{55}$ Two caveats are, however, appropriate. First, moral engagement within any given community takes place within specific discursive parameters for the realisation of pre-moral value. Law, in the form of statutes and precedent, plays a significant role in maintaining these institutional boundaries. In other words, although multiple institutional arrangements are consistent with respect for the basic values, particular legal communities will come to reflect defined frameworks for ethical realisation. These evolved frameworks, insofar as they do not conflict with basic ethical demands, may justly claim moral force, even though their exact form is ethically contingent. This is similar to the way that, according to Thomas Aquinas, positive rules may properly be derived from the natural law as implementations of general directives'. ${ }^{56}$ Respect for pre-moral value requires a stable legal framework for human behaviour, but the pre-moral dimension does not itself specify the framework in all its detail.

There is another reason why the questions upon which legal officials must pass judgement are sometimes properly regarded as foreclosed by moral considerations. Everyday moral deliberation concerns the way a person realises value in her or his own activities; legal deliberation, on the other

${ }^{53}$ Finnis describes the basic goods as 'open-ended'. See John Finnis, 'Natural Law and Legal Reasoning' in Robert P George (ed), Natural Law Theory: Contemporary Essays (1992) 134, 142.

${ }^{54}$ Ibid 151-2.

55 John Finnis, 'On Reason and Authority in Law's Empire' (1987) 6 Law and Philosophy 357, 371. See also John Finnis, 'Natural Law and Legal Reasoning' (1990) 38 Cleveland State Law Review 1, 7.

${ }^{56}$ See Finnis, above n 41, 284; Finnis, above n 47, 266-74; Finnis, 'Natural Law and Legal Reasoning', above n 55, 12. 
hand, concerns the imposition of generalised rules upon the engagement of individuals with the social environment. Respecting the autonomy of the moral subject entails avoiding unnecessary interference with her or his choice of substantive moral commitments, subject only to the constraints imposed by the basic values. ${ }^{57}$ It follows that legal officials should only deliberately interfere with individual choices to remedy or avoid an ethical wrong. In an ideal world, every appeal to legal officials would have an ethical basis. In practice, however, legal institutions tend to provoke rent seeking behaviours, whereby people seek preferential support for their individual moral priorities, although their moral rights have not been violated. Such ungrounded appeals to legal authority should properly go unheeded.

In this way, the generalised nature of legal authority suggests that there will be a 'right' answer to legal questions more frequently than for normative deliberation generally. Of course, as Dworkin frequently points out, ${ }^{58}$ the view that legal cases may admit a correct answer does not entail that the relevant outcome can be proved right to the satisfaction of everyone. Law should be regarded as a form of social discourse that engages reflectively with the ethical context presented in everyday experience. In practice, what matters is that the ethical foundations of legal deliberation are taken seriously. The importance of ethically grounding legal decisions signifies the true value of integrity.

57 Compare John Finnis, 'Is Natural Law Theory Compatible with Limited Government?' in Robert P George (ed), Natural Law, Liberalism and Morality: Contemporary Essays (1996) 1.

${ }^{58}$ See, for eg, above n 4, ix. 